\title{
ANALYSIS OF AIRPORT GROUND ACCESS SERVICES BY SP/RP MODEL WITHIN THE SCOPE OF HASAN POLATKAN AIRPORT MASTER PLAN
}

\author{
DOI: 10.17261/Pressacademia.2020.1286 \\ JMML- V.7-ISS.3-2020(4)-p.143-153
}

\section{Savas S. Ates}

Eskisehir Technical University, Aviation Management, Eskisehir, Turkey. ssates@eskisehir.edu.tr, ORCID: 0000-0003-2462-0039

Date Received: June 14, 2020

Date Accepted: September 7, 2020

\section{To cite this document}

Ates, S.S, (2020). Analysis of airport ground access services by Sp/Rp model within the scope of Hasan Polatkan Airport Master Plan. Journal of Management, Marketing and Logistics (JMML), V.7(3), p.143-153.

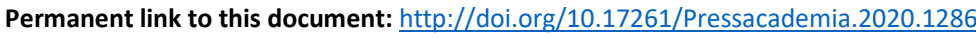

Copyright: Published by Press Academia and limited licensed re-use rights only.

\begin{abstract}
Purpose - The airport master plan should include requirements and recommendations, demand forecasts, environmental analysis, layout plan, facility requirements, financial size, and location selection information. The biggest factor in choosing air transportation by passengers is that it is a fast and comfortable mode of transportation. Since the transportation time and ease of the airport is also a factor affecting this factor, its integration with airport access roads, intercity connecting roads and other modes of transportation is important for the passengers to choose air transportation. Therefore, the importance of airport access roads in master plan studies can be understood more clearly. Aim of the study is that analyzing to airport ground access services of Hasan Polatkan Airport within the scope of master plan.

Methodology - In the first part of the research, the airport planning steps are examined in the literature. Airport ground access services data was collected with the secondary data. Revealed preferences surveys (RP) and stated preferences surveys (SP) were used to get he data of the passengers' satisfaction. A statistical program used to analysis of survey. Total of 91 passengers were reached in 3 different flights in 2018 in the summer. The scale of the research was adapted from the Passenger Time Value, Benefit-Cost Analysis and Airport Capital Investment Decisions book

Findings- Only 15.4 percent of the passengers use public transportation to access the airport. Conducted with the passengers at the Eskişehir Hasan Polatkan Airport Terminal Section, the passengers were generally satisfied with the transportation conditions to the airport. The primary mode of transportation preferred for RP in access to the airport is light rail systems.

Conclusion- Survey form to evaluate the airport transportation services in terms of passengers was prepared and applied on outgoing incoming passengers. As a consequence of the analysis of the research, suggestions about Hasan Polatkan airport were completed.
\end{abstract}

Keywords: Airport planning, airport services, Hasan Polatkan Airport, SP/RP model.

JEL Codes: L91, L93, L98

\section{INTRODUCTION}

Airport projects are important incomes the countries. Airports are the projects that change the transportation structure by affecting the region where it is built socially also economically (Coogan, 2008). Investment sources of airport construction projects require a huge budget. Therefore, proper planning of airport investments is important for the efficient use of public resources. It has developed sustainable methods with long-term planning for airport management. Because managing economic uncertainty and rapid market changes in the air transport industry requires long-term plans (Salamone, 2009). Airport planning can be designed for new or existing airports. Investments of an airport; financially, architectural structure and socio-economic requires detailed analysis. Therefore, it is imperative to analyze future expectations in the construction of the airport (Greenberger, 2010). Air transport planning is classified according to the size of the scope of the approach. In this respect, long-term planning is evaluated according to three different sizes: national transportation planning, aviation system planning and airport system planning (Caves and Gosling, 1999). Airport landside is the process of analyzing facilities with capacity analysis. In airport landside capacity analysis, structures for passengers, greeters, air cargo and land transportation vehicles are analyzed.

Over the past decade, changes in the management of the airline industry have had profound effects on the ground transportation patterns to major airports (Gosling, 2008). The prediction of air passenger and airport employee mode choice decisions for travel 
to and from the airport forms a key analytical component of airport landside planning, as well as airport system planning. However, there is currently no generally accepted and validated approach to modeling how airport users will change their access or egress mode in response to changes in the airport ground transportation system. The factors affecting airport travel are recognized as being significantly different from those affecting typical trips accounted for in regional transportation models. Therefore, it is difficult to determine the economic feasibility of proposed projects to improve airport ground transportation or effectively manage the existing airport ground transportation system using traditional regional models (Coogan, 2008).

\section{LITERATURE REVIEW}

The expectations of the passengers on the airport landside are high as parking, ticket sales and check-in, baggage handling (Gosling, 2008). The passenger of an airport should be analyzed by demand forecast methodology. The future demands of the airport are tried to be estimated by examining many data as the passenger's age, income status, travel purpose, destination cities, number of trips, number of luggage and etc. Size of the airport is determined according to the estimated number of passengers. Services at the airport are designed in accordance with national and international aviation regulations. In the airport services, many processes such as passenger processing time, walking distance, and etc. should be at the level of national and international standards (Ateş, 2006).

\subsection{Scope of Master Planning in Small Scale Airports}

Air transportation have a dynamic structure that changes daily. Therefore, it is difficult to achieve a stable balance at the airports (Nixon, 2014). There are many factors that affect he number of scheduled passengers at an airports (Landau, Weisbrod, Gosling, and Williges, 2015). These factors are changing of population distribution, passenger travel habits, and political regime, and etc. (Ashford and Wright, 1992). Airport planning levels and the planning process of each level are summarized in Table 1.

\section{Table 1: Airport Planning Levels}

\begin{tabular}{|c|c|c|}
\hline $\begin{array}{l}\text { NAME of } \\
\text { PLANNING }\end{array}$ & PROCESS of PLANNING & $\begin{array}{c}\text { LEVEL of } \\
\text { PLANNING }\end{array}$ \\
\hline $\begin{array}{l}\text { Aviation System } \\
\text { Planning }\end{array}$ & $\begin{array}{l}\text { 1. Setting Goals and Objectives } \\
\text { 2. Identification of existing strategic systems } \\
\text { 3. Conducting long-term demand analyzes } \\
\text { 4. Creating scenarios } \\
\text { 5. Evaluation of the scenarios } \\
\text { 6. Selecting of the most suitable aviation system plan }\end{array}$ & $\begin{array}{l}\text { Strategic } \\
\text { planning }\end{array}$ \\
\hline $\begin{array}{l}\text { Airport System } \\
\text { Planning }\end{array}$ & $\begin{array}{l}\text { 1. Identification of the existing airport system } \\
\text { 2. Demand analysis } \\
\text { 3. Creating scenarios } \\
\text { 4. Propose of the alternates to development of the airport system } \\
\text { 6. Evaluation } \\
\text { 7. Selecting of the most suitable airport system plan }\end{array}$ & $\begin{array}{l}\text { Strategic } \\
\text { planning }\end{array}$ \\
\hline
\end{tabular}

For each airport

\begin{tabular}{|c|c|c|}
\hline $\begin{array}{l}\text { Airport Master } \\
\text { Planning }\end{array}$ & $\begin{array}{l}\text { 1. Identification of the existing facilities of the airport } \\
\text { 2. Demand analysis } \\
\text { 3. Propose of airport development alternates } \\
\text { 4. Evaluation of the alternates } \\
\text { 5. Selection of the most appropriate alternates }\end{array}$ & $\begin{array}{l}\text { Strategic and } \\
\text { Tactical } \\
\text { Planning }\end{array}$ \\
\hline $\begin{array}{l}\text { Airport } \\
\text { Development } \\
\text { Implementation } \\
\text { Plan }\end{array}$ & $\begin{array}{l}\text { 1. Propose of different project alternates } \\
\text { 2. Selection of project plans } \\
\text { 3. The best execution of the project }\end{array}$ & $\begin{array}{c}\text { Tactical and } \\
\text { Project Planning }\end{array}$ \\
\hline
\end{tabular}

The first step in the preparation of the airport master plan is to collect data on the region served by the airport (Saldıraner, 2013). One of the elements to be analyzed during the current situation analysis is airport ground access (Kwakkel, Kwakkel, and Marchau, 
2010). Safety, speed, cost and comfort are considered in the choice of transportation type of passengers (Pucci and Lanza, 2019). In airport planning, suitable transportation types that will meet the transportation needs of the passengers from the origin point to the destination point must be taken into consideration.

Small-scale airports have a minimum budget. These airports are designed to serve as the general aviation or commercial flights also, they are generally focused on narrow (niche) market. It is important to recognize niche market and provide correct service in the development of marketing strategies and tactics of small-scale airports (Greenberger, 2010). Ground access to the airport is also one of the important points to planning of small-scale airports. The vast majority of these airports are operated by a limited employee. However, the analyze of the market with stakeholders is not problematic because of the scale. On the other hand, the lack of expert teams for these airports is one of the important obstacles.

\subsection{Ground Access to the Airport}

Airline transportation duration of travel time is shortened from the first point (origin) to the last point (destination) of the passenger or the customer of air cargo (Landau, 2015). In this sense, when the travel time is mentioned, the time from the city to the airport or from the airport to the city, and the time spent in the air and/or in the terminal building should be considered. Travel time should be understood as the time when are the duration from the origin city to the airport, from the destination airport to the city, as well as the time in the terminal building and in the air (Gokasar and Gunay, 2016). Some of the literature that use different methodology according to these objectives in the literature for access to the airport are summarized in Table 2.

Table 2: Airport Planning Levels

\begin{tabular}{|c|c|c|}
\hline Name-Ref & Methodology & Purpose \\
\hline (Akar, 2013) & Principal Component Analyses & Ground access mode choices \\
\hline (Alhussein, 2011) & Binary Logit Model & Ground access modes choice \\
\hline (Budd, Ryley, and Ison, 2014) & Segmentation Analysis & Access private car use \\
\hline (Chang, 2013) & Self-administered questionnaire & Mode choice of elderly pax \\
\hline (Cirillo and Xu, 2010) & Multinomial, NL, RP/SP & $\begin{array}{l}\text { Cybernetic transportation system forcast } \\
\text { for airport access }\end{array}$ \\
\hline (Cunningham and Gerlach, 1998) & Focus group discussions & Airport ground access planning \\
\hline (Jou, Hensher, and Hsu, 2011) & The mixed logit (MXL), RP/SP & $\begin{array}{l}\text { Mode choice behavior after the } \\
\text { introduction of a new mode }\end{array}$ \\
\hline $\begin{array}{l}\text { (Llorca, Zhang, Moreno, and Moeckel, } \\
\text { 2019) }\end{array}$ & Agent-based travel demand model & Airport access and egress trips \\
\hline (Mantecchini and Paganelli, 2016) & Paradox of Bi-Modal Networks & Regional and urban airports ground access \\
\hline (Pasha and Hickman, 2017) & Review and Assessment & $\begin{array}{l}\text { Airport employees' ground } \\
\text { accessibility }\end{array}$ \\
\hline (Tam and Lo, 2011) & MMNL, CNL & $\begin{array}{l}\text { Travel Time Reliability Perceived Service } \\
\text { Quality }\end{array}$ \\
\hline (Tsamboulas and Nikoleris, 2008) & Statistical analysis & $\begin{array}{l}\text { Passengers' willingness to pay for ground } \\
\text { time saving }\end{array}$ \\
\hline
\end{tabular}

When traveling from an airport, facility planning, terminal design, service decisions taken jointly with the airline, stakeholder evaluations are needed to reduce travel time and delays. It is observed that people going to airports often rush and compete over time (National Research Council, 1996). Effective transportation time for passengers can be calculated as shown in Figure 1. airport ground access time varies depending on the modes of transportation used by passengers (Landau, Weisbrod, Gosling, and Williges, 2015). 
Figure 1: Effectiveness of Transport Time

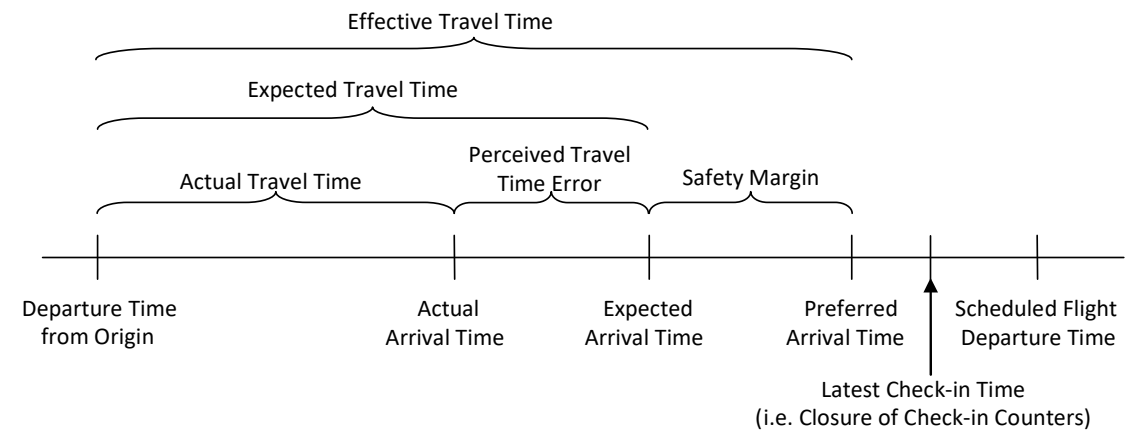

Source: (Tam, Lam, and Lo, 2008)

The value of time (Value of Advanced Travel Time, Landau, 2015) refers to what people are willing to pay to save time or the time they want to endure to save money. It is known that the time value of the journey varies according to the purpose and mode of the journey. Access to the airport is only one of the items used in calculating the advanced time value and others are shown Table 3 (Landau, 2015). Calculation items of time value of journey includes ground access time to the airport, terminal access time, check-in and security time, time to reach the gate, and boarding time for the Terminal Land Side.

Table 3: Calculation Items of Time Value of Journey

\begin{tabular}{cl}
\hline Air / Land Side & Item of Time Calculation \\
\hline & Ground access time to the airport \\
Terminal Land Side & $\begin{array}{l}\text { Terminal access time } \\
\text { Check-in and security time } \\
\text { (Departure) }\end{array}$ \\
& $\begin{array}{l}\text { Time to reach the gate } \\
\text { Boarding time }\end{array}$ \\
Air Side & Flight time \\
(Flight) & Unexpected flight delay \\
Terminal Landside & Time to reach or leave baggage claim \\
(Arrival) & Baggage claim waiting time and exit time \\
& Time to leave the airport \\
\hline
\end{tabular}

Source: Landau, 2015

\section{DATA AND METHODOLOGY}

Hasan Polatkan Airport Master Plan, one of the secondary data sources, was examined in order to reach the aim of this study. The published documentation of the municipality's transportation line was collected via the Internet. In order to clarify the meaningful information, in-depth analyzes were made and the passengers and their half / Stated Preferences views and satisfaction in accessing the airport were asked. Within the scope of the research, a total of 91 passengers were reached in 3 different flights in 2018 in the summer. The scale of the research was adapted from the Passenger Time Value, Benefit-Cost Analysis and Airport Capital Investment Decisions book (Landau, 2015).

Figure 2: Research Methodology Diagram

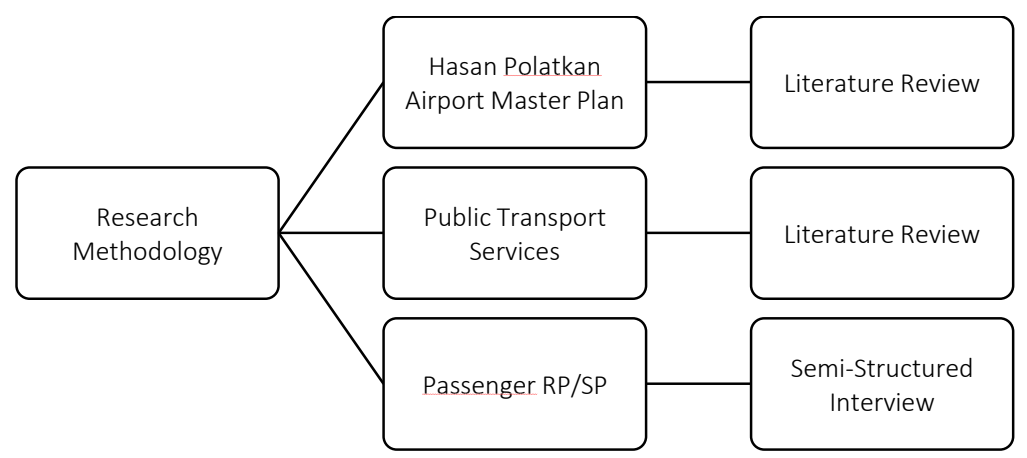


Revealed preferences surveys (RP) are about individuals have actually made choices. In terms of a public transport surveys, revealed information would be actual trip or trips made by the user considering origin, destination, origin stop, destination stop, journey purpose, and the mode of transport they chose to use from the available alternatives. The strong point of this type of survey is that it provides us real choices made by users in a determined context of constraints. On the other hand, stated preferences surveys (SP) collect replies to hypothetical situations in this case about public transport- presented to users. This type of survey tries to overcome some of the limitations of RP surveys. One of the limitations of RP surveys is that many scenarios provide insufficient variability in the observations, observed behavior could be difficult to relate with certain qualitative variables (e.g., comfort) and the impossibility of measuring choices between alternatives that do not exist yet (Olio, Ibeas, Ona, and Ona, 2017). The data obtained as a result of the research has been used to make changes in Hasan Polatkan Airport Master Plan. In addition, improvements are planned by sharing data with the public transport authorities of the region.

\section{FINDINGS AND DISCUSSIONS}

\subsection{Hasan Polatkan Airport}

Hasan Polatkan Airport, which was opened to traffic on 29 March 1989 under the name of Anadolu Airport, is an International airport operated by the Faculty of Aviation and Space Sciences on behalf of the Rectorate of Anadolu University (Eskisehir Technical University). In this context, airport operation, terminal operation, air traffic control services and flight training activities are effectively carried out. In addition, applied trainings that are compatible with the education areas of faculty students are provided.

Between Hasan Polatkan University Airport and Eskişehir-Istanbul;

Figure 2: Hasan Polatkan Airport Flights

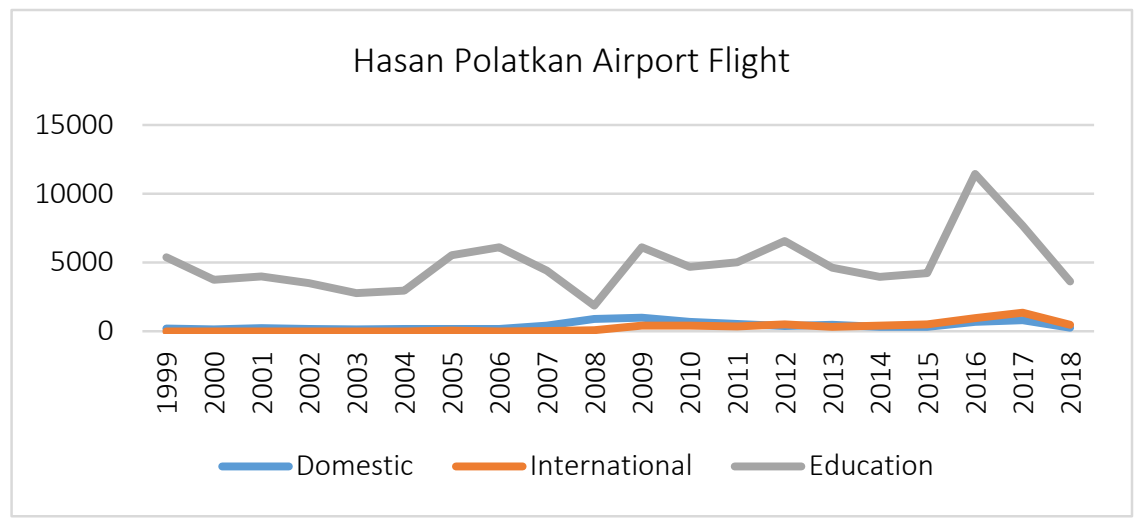

- Imsık Air between 1990-1991,

- TOP AIR from 1995-1996

- Domestic flights were organized by Turkish Airlines in 1997-1998.

- International flights started in May 2005.

\subsection{Ground Access of Hasan Polatkan Airport}

Hasan Polatkan Airport is north of Eskişehir, $5 \mathrm{~km}$ from the city center. away from the Muttalip location, within the Eskisehir Technical University Iki Eylül Campus. Access to the airport can only be provided by road. It is possible to reach the airport by using the Sarıcakaya junction of the D200 highway or via Gazi Yakup Satar Avenue for transportation from the city center. Only highway is possible for transportation to the airport. 
Table 4: Time Value of Hasan Polatkan Airport

\begin{tabular}{|c|c|c|c|c|}
\hline Mode & $\begin{array}{c}\text { Travel Cost } \\
\text { (TL) }\end{array}$ & $\begin{array}{c}\text { Travel } \\
\text { time } \\
\text { (minutes) }\end{array}$ & Headway & $\begin{array}{l}\text { Hours of } \\
\text { operation }\end{array}$ \\
\hline Public Bus (K-4)a & 3,50 & 30 & $10-20-30 \mathrm{~min}$ & $07: 00$ to $20: 00$ \\
\hline Public Bus (M-4) ${ }^{\mathrm{b}}$ & 3,50 & 25 & $20 \mathrm{~min}$ & $08: 00$ to $18: 00$ \\
\hline Public Bus (S-56) ${ }^{c}$ & 3,50 & 60 & 10 hours & $08: 00$ to $17: 30$ \\
\hline Public Bus (S-85) ${ }^{d}$ & 3,50 & 65 & & $08: 00$ to $17: 40$ \\
\hline Private operated bus & 50 & 120 & Dep-Arr Airline & Dep-Arr Airline \\
\hline Taxi (City to Airport) & 20 & 20 & - & - \\
\hline Taxi (Emirdag to Airport) & 220 & 90 & - & - \\
\hline Private Car (City to Airport) ${ }^{\mathrm{e}}$ & 8 & 20 & - & - \\
\hline Private Car (Emirdag to Airport) ${ }^{\mathrm{e}}$ & 90 & 90 & - & - \\
\hline Rent a vehicle (Emirdag to Airport) ${ }^{f}$ & 250 & 90 & - & - \\
\hline \multicolumn{5}{|c|}{$\begin{array}{l}\text { a The K- } 4 \text { bus line usually runs every } 10 \text { minutes (from } 5 \text { am in the morning and every } 20 \text { minutes after 18:00) on weeken } \\
\text { public holidays and schools from 07:00 to 20:00 on weekdays. when it is off, it moves every } 30 \text { minutes from 08:00 } \\
\text { 20:00 (EBB, 2019). } \\
\text { b There are no trips during the weekend, public holidays and when the school is on holiday. (EBB, 2019). } \\
\text { c This bus line runs once a day, 08:00 and 17:30, and does not work on weekends and public holidays. (EBB, 2019). } \\
\text { d This bus line runs once a day, 08:00 and 17:40, and does not work on weekends and public holidays. (EBB, 2019). } \\
\text { e Estimated fuel consumption. There is no parking fee at the airport. } \\
\text { f Since there is no rent a car office at the airport, driver rental should be done. }\end{array}$} \\
\hline
\end{tabular}

Since the public bus line is especially for university students, it is not served in accordance with the flight hours. When the bus lines are examined, they do not provide services in accordance with flight times and are not a service that passengers can benefit from.

Figure 3: Analysis Framework for Main Line Access Mode Choice
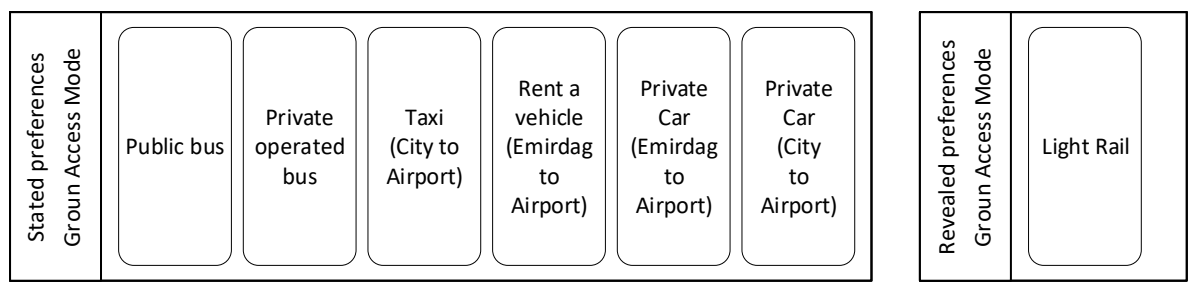

\subsection{Survey Analysis}

82.4 percent of the passengers surveyed (75 passengers) are citizen of the Republic of Turkey, and 16.5 percent (15 passengers) are dual citizenship. Only 1.1 percent (1 passenger) is the citizens of France. 68.1 percent (62 passengers) of the participants are men and 31.9 percent (29 passengers) are women (Table 5).

Table 5: Gender

\begin{tabular}{llrrrr}
\hline & & & $\begin{array}{r}\text { Valid } \\
\text { Percent }\end{array}$ & $\begin{array}{r}\text { Cumulative } \\
\text { Percent }\end{array}$ \\
\hline Valid & Male & 62 & 68,1 & 68,1 & 68,1 \\
& Female & 29 & 31,9 & 31,9 & 100,0 \\
& Total & 91 & 100,0 & 100,0 & \\
\hline
\end{tabular}

7.8 percent of participating passengers are under 20 years old, 25.6 percent are between $20-30$ years old, 30 percent are between 31-40 years old, and 14.4 percent are over 60 years old Table 6 . 
Table 6: Age

\begin{tabular}{llrrrr}
\hline & & & & Cumulative \\
Valid & Under 20 & 7 & 7,7 & 7,8 & 7,8 \\
& $20-30$ & 23 & 25,3 & 25,6 & 33,3 \\
& $31-40$ & 27 & 29,7 & 30,0 & 63,3 \\
& $41-50$ & 8 & 8,8 & 8,9 & 72,2 \\
& $51-60$ & 12 & 13,2 & 13,3 & 85,6 \\
& 60 Above & 13 & 14,3 & 14,4 & 100,0 \\
& Total & 90 & 98,9 & 100,0 & \\
Missing & System & 1 & 1,1 & & \\
Total & & 91 & 100,0 & & \\
\hline
\end{tabular}

When asked about w educational status, 33 percent of the participants were at the level of middle primary education and middle school (Table 7).

Table 7: Graduation

\begin{tabular}{llrrrr}
\hline & & & $\begin{array}{r}\text { Valid } \\
\text { Percent }\end{array}$ & $\begin{array}{r}\text { Cumulative } \\
\text { Percent }\end{array}$ \\
\hline Valid & Primary education & 12 & 13,2 & 13,2 & 13,2 \\
& Middle school & 18 & 19,8 & 19,8 & 33,0 \\
& High school & 38 & 41,8 & 41,8 & 74,7 \\
& University & 23 & 25,3 & 25,3 & 100,0 \\
& Total & 91 & 100,0 & 100,0 & \\
\hline
\end{tabular}

The usage rates of passengers Hasan Polatkan Airport are given in Table 8. According to the table, 86.8 percent of the participants use the airport more than once a time in one year.

Table 8: Use the Airports (Annually)

\begin{tabular}{|c|c|c|c|c|c|}
\hline & & Frequency & Percent & $\begin{array}{r}\text { Valid } \\
\text { Percent }\end{array}$ & $\begin{array}{r}\text { Cumulative } \\
\text { Percent }\end{array}$ \\
\hline \multirow[t]{6}{*}{ Valid } & Only 1 & 12 & 13,2 & 13,2 & 13,2 \\
\hline & $2-3$ & 17 & 18,7 & 18,7 & 31,9 \\
\hline & $4-6$ & 38 & 41,8 & 41,8 & 73,6 \\
\hline & $7-10$ & 9 & 9,9 & 9,9 & 83,5 \\
\hline & More than 10 & 15 & 16,5 & 16,5 & 100,0 \\
\hline & Total & 91 & 100,0 & 100,0 & \\
\hline
\end{tabular}

Only $17 \%$ of the travel aim of the interviewed passengers are business purposes. The primary aim of the majority is for holiday and relative visits. In addition, although there is an option in the survey as health tourism, however there isn't any passenger choose this option.

\section{Table 9: Purpose of Travel}

\begin{tabular}{llrrrr}
\hline & & & $\begin{array}{r}\text { Valid } \\
\text { Percent }\end{array}$ & $\begin{array}{r}\text { Cumulative } \\
\text { Percent }\end{array}$ \\
\hline Valid & Visiting relatives and friends & 38 & 41,8 & 41,8 & 41,8 \\
& Holiday & 36 & 39,6 & 39,6 & 81,3 \\
& Business travel & 17 & 18,7 & 18,7 & 100,0 \\
& Total & 91 & 100,0 & 100,0 & \\
\hline
\end{tabular}

Only 15.4 percent of the passengers use public transportation to access the airport (Public Bus, Private operated bus). When the distribution of the transportation preferences of the participants is analyzed, the ratio of the passengers who prefer the taxi is 41.8 percent and the rate of those arriving by private car and rental car is 42.9 percent. 
Table 10: Ground Access

\begin{tabular}{llrrrr}
\hline & Frequency & Percent & $\begin{array}{r}\text { Valid } \\
\text { Percent }\end{array}$ & $\begin{array}{r}\text { Cumulative } \\
\text { Percent }\end{array}$ \\
\hline Valid & Public bus & 6 & 6,6 & 6,6 & 6,6 \\
& Private operated bus & 8 & 8,8 & 8,8 & 15,4 \\
& Taxi (City to Airport) & 38 & 41,8 & 41,8 & 57,1 \\
& Rent a vehicle (Emirdag to Airport) & 3 & 3,3 & 3,3 & 60,4 \\
& Private Car (Emirdag to Airport) & 15 & 16,5 & 16,5 & 76,9 \\
Private Car (City to Airport) & 21 & 23,1 & 23,1 & 100,0 \\
Total & 91 & 100,0 & 100,0 & \\
\hline
\end{tabular}

Passengers using the airport were asked about ground services alternatives and satisfaction with likert-type scale. 50.5 percent of the participants are satisfied with the access alternatives to the airport. The reason for the dissatisfaction of the remaining 49.5 in the revealed preferences surveys (RP) stage was determined as a subject to be investigated (Table 11).

Table 11: Ground access alternatives to the airport is sufficient.

\begin{tabular}{lrrrr}
\hline & Frequency & Percent & $\begin{array}{r}\text { Valid } \\
\text { Percent }\end{array}$ & $\begin{array}{r}\text { Cumulative } \\
\text { Percent }\end{array}$ \\
\hline Strongly agree & 3 & 3,3 & 3,3 & 3,3 \\
Agree & 43 & 47,3 & 47,3 & 50,5 \\
Neutral & 16 & 17,6 & 17,6 & 68,1 \\
Disagree & 23 & 25,3 & 25,3 & 93,4 \\
Strongly disagree & 6 & 6,6 & 6,6 & 100,0 \\
Total & 91 & 100,0 & 100,0 & \\
\hline
\end{tabular}

According to Table 12, 60.4 percent of the respondents stated that they had easy access to Hasan Polatkan Airport.

Table 12: I can easily reach to the airport.

\begin{tabular}{llrrrr}
\hline & Frequency & Percent & $\begin{array}{r}\text { Valid } \\
\text { Percent }\end{array}$ & $\begin{array}{r}\text { Cumulative } \\
\text { Percent }\end{array}$ \\
\hline Valid & Strongly agree & 5 & 5,5 & 5,5 & 5,5 \\
& Agree & 50 & 54,9 & 54,9 & 60,4 \\
& Neutral & 14 & 15,4 & 15,4 & 75,8 \\
& Disagree & 21 & 23,1 & 23,1 & 98,9 \\
& Strongly disagree & 1 & 1,1 & 1,1 & 100,0 \\
& Total & 91 & 100,0 & 100,0 & \\
\hline
\end{tabular}

In order to understand RP more deeply in accessing the airport, it was asked whether the public transportation service is suitable for the flight program. Only 17.8 percent of the respondents think that public transportation facilities are arranged according to the flight schedule (Table 13).

Table 13: I think that there is a public transportation service in accordance with the flight schedule.

\begin{tabular}{llrrrr}
\hline & & Frequency & Percent & $\begin{array}{r}\text { Valid } \\
\text { Percent }\end{array}$ & $\begin{array}{r}\text { Cumulative } \\
\text { Percent }\end{array}$ \\
\hline Valid & Agree & 16 & 17,6 & 17,8 & 17,8 \\
& Neutral & 39 & 42,9 & 43,3 & 61,1 \\
& Disagree & 25 & 27,5 & 27,8 & 88,9 \\
& Strongly disagree & 10 & 11,0 & 11,1 & 100,0 \\
& Total & 90 & 98,9 & 100,0 & \\
Missing & System & 1 & 1,1 & & \\
Total & & 91 & 100,0 & & \\
\hline
\end{tabular}

Stated preferences surveys (SP) collect replies to hypothetical situations presented to users, in this case about public transport. 79.1 percent of the passengers participating in the research stated that they need alternative transportation types to access the airport (Table 14). 
Table 14: I need alternative ground access modes.

\begin{tabular}{llrrrr}
\hline & & & Valid & Cumulative \\
& & Frequency & Percent & Percent & Percent \\
\hline Valid & Strongly agree & 51 & 56,0 & 56,0 & 56,0 \\
& Agree & 21 & 23,1 & 23,1 & 79,1 \\
& Neutral & 2 & 2,2 & 2,2 & 81,3 \\
& Disagree & 8 & 8,8 & 8,8 & 90,1 \\
& Strongly disagree & 9 & 9,9 & 9,9 & 100,0 \\
& Total & 91 & 100,0 & 100,0 & \\
\hline
\end{tabular}

Moreover, stated preferences surveys (SP) Hasan Polatkan stated that $79.1 \%$ of the participants will use the light rail when arriving to the airport, if there is a light rail, such as a subway, to reach the airport (Table 15).

Table 15: I would also like to have light rail vehicles to reach the airport.

\begin{tabular}{llrrrr}
\hline & Frequency & Percent & $\begin{array}{r}\text { Valid } \\
\text { Percent }\end{array}$ & $\begin{array}{r}\text { Cumulative } \\
\text { Percent }\end{array}$ \\
\hline Valid & Strongly agree & 60 & 65,9 & 65,9 & 65,9 \\
& Agree & 12 & 13,2 & 13,2 & 79,1 \\
& Neutral & 4 & 4,4 & 4,4 & 83,5 \\
& Disagree & 3 & 3,3 & 3,3 & 86,8 \\
& Strongly disagree & 12 & 13,2 & 13,2 & 100,0 \\
& Total & 91 & 100,0 & 100,0 & \\
\hline
\end{tabular}

One of the situations questioned within the scope of SP analysis is the increase in flight frequency. $68.1 \%$ of the respondents stated that it would be difficult to reach the airport if the flights to the airport increased. In face-to-face interviews, one of the problems that may arise in increasing flight frequency is stated as airport parking problem (Table 15).

Table 16: I think that it will be difficult to reach the airport as flight flights become more frequent.

\begin{tabular}{llrrrr}
\hline & & & Valid & Cumulative \\
& & Frequency & Percent & Percent & Percent \\
\hline Valid & Strongly agree & 23 & 25,3 & 25,3 & 25,3 \\
& Agree & 39 & 42,9 & 42,9 & 68,1 \\
& Neutral & 10 & 11,0 & 11,0 & 79,1 \\
& Disagree & 19 & 20,9 & 20,9 & 100,0 \\
& Total & 91 & 100,0 & 100,0 & \\
\hline
\end{tabular}

\section{CONCLUSION}

As a result of the surveys conducted with the passengers at the Eskişehir Hasan Polatkan Airport Terminal Section, the passengers were generally satisfied with the transportation conditions to the airport. The vast majority of the passengers asks for different alternatives to access to the airport. In the revealed preferences surveys analysis, the majority of the passengers who ask for different alternatives are above middle age passengers. The primary mode of transportation preferred for RP in access to the airport is light rail systems.

Most of the passengers who traveled from the city center complain about the bus schedule because it is not fit for the flight schedule. Also, there is no shuttle service and the trams to the airport. Passengers providing transportation from other city (Emirdağ) stated that there is no alternative to access to the airport other than the private operated bus. The vast majority of the participants stated that they do not have any difficulties in their access to Hasan Polatkan Airport under current conditions, but they will have difficulties if the flight frequency increases. When all these data are examined, the vast majority of the passengers comes from Emirdağ district of Afyon. Taking this into account, Emirdağ access should be planned with alternative means of ground access that fits with the flight hours.

A bus service can be added to the Hasan Polatkan Airport. In addition, it is seen that there is no suitable service for passengers coming from the city. It turned out that bus lines that operate to the airport work in accordance with the students' timetable at the University Campus. It is recommended to provide an airport ring line in accordance with flight schedule. Moreover, an additional public bus service can be added to city-airport line. Integration between modes should be provided in terms of airport 
master planning. For this reason, it should be remembered that alternatives have to be planned from outside of Eskişehir to the city center (bus station or train station) and vice versa.

\section{REFERENCES}

Akar, G. (2013). Ground access to airports, case study: Port Columbus International. Journal of Air Transport Management, 30, 25-31. doi:http://dx.doi.org/10.1016/j.jairtraman.2013.04.002

Alhussein, S. N. (2011). Analysis of ground access modes choice King Khaled International Airport, Riyadh, Saudi Arabia. Journal of Transport Geography, 19, 1361-1367. doi:doi:10.1016/j.jtrangeo.2011.07.007

Ashford, N., and Wright, P. H. (1992). Airport Engineering. New York: A Wiley-Interscience Publication.

Ateş, S. S. (2006). Havaalanı Master Planlama Yaklaşımları. Eskişehir: Anadolu Üniversitesi Sosyal Bilimler Enstitüsü Havacılık Yönetimi ABD. Yayınlanmamış Yükseklisans Tezi.

Budd, T., Ryley, T., and Ison, S. (2014). Airport ground access and private car use: a segmentation analysis. Journal of Transport Geography, 106115.

Caves, R. E., and Gosling, G. D. (1999). Strategic Airport Planning. Amsterdam: Pergamon.

Chang, Y.-C. (2013). Factors affecting airport access mode choice for elderly air passengers. Transportation Research Part E(57), 105-112. doi:http://dx.doi.org/10.1016/j.tre.2013.01.010

Cirillo, C., and Xu, R. (2010). Forecasting Cybercar Use for Airport Ground Access: Case Study at Baltimore Washington International Airport. Journal of Urban Planning and Development, 136(3), 186-194.

Coogan, M. A. (2008). Ground Access to Major Airports by Public Transportation. Washington, DC: The National Academies Press.

Cunningham, L. F., and Gerlach, J. H. (1998). Transportation agencies' experiences with decision support systems for airport ground access planning. Transportation, 25(1), 37-53.

EBB. (2019, Aralık 20). Eskişehir Büyük Şehir Belediyesi. Otobüs Güzergahı Sorgula: http://www.eskisehir.bel.tr/otobus_saatleri_guzergah_get.php adresinden alındı

Gokasar, I., and Gunay, G. (2016). Mode choice behavior modeling of ground access to airports: A case modeling of ground access to airports: A case. Journal of Air Transport Management(59), 1-7. doi:http://dx.doi.org/10.1016/j.jairtraman.2016.11.003

Gosling, G. D. (2008). Airport Ground Access Mode Choice Models. Washington, DC: The National Academies Press.

Greenberger, M. A. (2010). Marketing Guidebook for Small Airports. Washington, DC: The National Academies Press. doi:https://doi.org/10.17226/14353.

Jou, R.-C., Hensher, D. A., and Hsu, T.-L. (2011). Airport ground access mode choice behavior after the introduction of a new mode: A case study of Taoyuan International Airport in Taiwan. Transportation Research Part E, 371-381. doi:10.1016/j.tre.2010.11.008

Kwakkel, J., Kwakkel, J., and Marchau, V. (2010). Adaptive Airport Strategic Planning. European Journal of Transport and Infrastructure Research (EJTIR), 10(3), 249-273. doi:https://doi.org/10.18757/ejtir.2010.10.3.2891

Landau, S. (2015). Passenger Value of Time, Benefit-Cost Analysis and Airport Capital Investment Decisions, Volume 1: Guidebook for Valuing User Time Savings in Airport Capital Investment Decision Analysis. Washington, DC: The National Academies Press. doi:https://doi.org/10.17226/22162.

Landau, S., Weisbrod, G., Gosling, G., and Williges, C. (2015). Passenger Value of Time, Benefit-Cost Analysis and Airport Capital Investment Decisions, Volume 2. Washington, DC: The National Academies Press. doi:https://doi.org/10.17226/22161

Llorca, C., Zhang, Q., Moreno, A., and Moeckel, R. (2019). Airport access and egress trips in an agent-based travel demand model. 8th Symposium of the European Association for Research in Transportation. Budapest: hEART 2019.

Mantecchini, L., and Paganelli, F. (2016). Airport ground access and urban congestion: a paradox of bi-modal networks. Contemporary Engineering Sciences, 30(9), 1491-1501. doi:https://doi.org/10.12988/ces.2016.68147

National Research Council. (1996). Airline Passenger Security Screening: New Technologies and Implementation Issues. Washington, DC: The National Academies Press. doi:https://doi.org/10.17226/5116.

Nixon, C. (2014). The dynamic planning approach and the death of the traditional master plan. Journal of Airport Management, 8(4), 343-350.

Oktal, H., and Ateş, S. S. (2010). Havaalanları Master Planlama Yaklaşımları ve Türkiye İçin Bir Öneri. UHUK'10 Eskişehir. Eskişehir: UHUK.

Olio, L. D., Ibeas, A., Ona, J. d., and Ona, R. d. (2017). Public Transportation Quality of Service: Factors, Models, and Applications. Elsevier.

Pasha, M. M., and Hickman, M. (2017). Airport Employees Ground Accessibility: Review and Assessment. In Australasian Transport Research Forum (ATRF). Auckland,: ATRF 2017 Proceedings. 
Pucci, P., and Lanza, G. (2019). High speed rail and airport. Future scenarios in Marco Polo Airport in Venice. Journal of Land Use, Mobility and Environment, 12(3), 265-282. doi:https://doi.org/10.6092/1970-9870/6072

Salamone, M. R. (2009). Strategic Planning in the Airport Industry. Washington, DC: The National Academies Press. doi:https://doi.org/10.17226/14339

Saldıraner, Y. (2013). Airport master planning in Turkey; planning and development problems and proposals. Journal of Air Transport Management(32), 71-77. doi:https://doi.org/10.1016/j.jairtraman.2013.07.003

Tam, M. L., Lam, W. H., and Lo, H. P. (2008). Modeling Air Passenger Travel Behavior on Airport Ground Access Mode Choices. Transportmetrica, 4(2), 135-153. doi:https://doi.org/10.1080/18128600808685685

Tam, M.-L., and Lo, W. H.-P. (2011). The Impact of Travel Time Reliability and Perceived Service Quality on Airport Ground Access Mode Choice. Journal of Choice Modelling, 4(2), 49-69.

Tsamboulas, D. A., and Nikoleris, A. (2008). Passengers' willingness to pay for airport ground access time savings. Transportation Research Part A, 1274-1282. doi:10.1016/j.tra.2008.03.013 